\title{
Impact of Foreign Direct Investment on the Development of Agricultural Economy in the Area of Korça
}

Msc. Eralda Shore

PhD Candidate at Agricultural University of Tirana

Msc Alvina Coku

Prof. As. Dr. Edmond Kadiu

Msc. Arjola Luci

Agriculture University of Tirana, Faculty of Economy and Agribusiness, Tirana, Albania eralda.shore@gmail.com

\section{Doi:10.5901/ajis.2016.v5n2p45}

\begin{abstract}
Korca district is among the biggest districts in the Republic of Albania. With a total of 365000 inhabitants, it is recognized as an area with developed agriculture and livestock, but as much as rich in tourist resources full of values. We will identify new unused resources mainly in agricultural products, which with their potential for increasing the income of rural residents, can directly affect the growth and development of Korca district. Real reflection of the situation in: (Drithas, Libonik, Lozhan, Mollas, Cumulus, Pojan, Maliq, Vithkuq, Bulgarec). Knowing the value of Foreign Direct Investment (FDI) as a mean for encouraging investment, stresses the need for accurate measurements and detailed statistics of FDI for assessing their relationship with economic growth and its impact on various economic sectors, mainly in the agricultural sector. The main goal is to identify the impact and the factors of prevention, in terms of increasing the flow of FDI in Albania. An important aspect of the purpose of this paper is to identify and assess the impact and the influence of FDI in Albanian agriculture, trends and issues or major obstacles to FDI in this sector, focusing in the Korca area and municipalities. In korca the inflow of foreign direct investment has played a role and has a significant impact on increasing productivity and efficiency of production, employment and domestic exports. The objectives of this study deal with the analysis of FDI as an important factor for developing countries in terms of globalization of the world economy as well as the direct or indirect impact they have on the Albanian economy with the main focus on agriculture. The specific objective of this paper is to identify and evaluate the competitive advantages of the area in order to attract foreign investment, with a focus on agriculture. In this context, to define how these advantages can be used and what the area needs, so it can attract more foreign investors.
\end{abstract}

Keywords: FDI, Agricultural Products, Business Climate, Willingness to Invest, the area of Korca, Growth Strategies.

\section{Introduction}

The geographical position of the area, the opportunity of trade links with other countries in the region and further promoted with the different cooperations, lead to very good results with positiv impact .In our opinion in order to promote foreign direct investment in Korce, several improvements in the reforms shall be taken.

These reforms should be undertaken in terms of the preservation of macroeconomic stability, the level of prices and the identification of positive and negative factors that influence in the attraction of foreign investments.

The significance of developments in recent years in Korce have positively impacted on the business climate in the country. For years, the business climate in Albania has been improving and growing interest of foreign investors comes and becomes greater, due to macroeconomic stability and implementation of reforms in the country.

Challenges in the future have to do with creating a climate more favorable to attract FDI in the country, including the construction of hydropower plants and new power plants as well as infrastructure and agricultural development, water supply,reduction of the land fragmentalitation problem.

Korca district is among the biggest districts in the Republic of Albania. It i composed of 6 cities (Korce, Pogradec, Maliq, Erseke, Bilisht, Leskovik), 31 municipalities.

Areas on focus (Maliq, Vithkuq, Bulgarec Drithas, Libonik, Lozhan, Mollas, Cumulus, Pojan,). 
In our research we have identified the following main specific objectives: Specific Objective (1): Building a comprehensive overview of FDI flows and their dynamics in Albania over the years, the main sectors where they are concentrated and areas where FDI flows are dispersed.

Specific Objective (2): To evaluate the role of FDI committed in Albania in the context of economic development and employment.

The specific objective (3) Assess the obstacles to growth of FDI flow in Albania and ways on how to eliminate or reduce them, in this context, analysis of the business climate and determining ways / roads / actions or conditions that must be fulfilled in order to increase the flow of FDI in the agricultural sector.

The business climate is negatively affected by high levels of tax, fiscal instability, unfair competition in the market and the relative insecurity of property rights and lower demand for agricultural products as a result of limited income of the population.

In the agricultural sector the business climate is affected negatively by the controversial political stability, perceptions of high level corruption, bad agricultural policies, farm size and its fragmentation, low quality of agricultural inputs, the disapproving trend of collective action and problems with irrigation and drainage infrastructure.

The business climate is affected positively,in the medium term, by relatively low standards of food safety, low environmental regulatory norms and the cost of manufacturing resources, mainly land and labor.

\section{Materials and Methods}

Research methodology is based on interviews / questionnaires. The two main questionnaires I've used are: the questionnaire of farmers and questionnaire survey for specialists, trading, processing businesses.) The first questionnaire reflects the current situation of 150 farmeres of the Korca area. Korca district is among the biggest districts in the Republic of Albania. In its composition there are presented the farmers questionnaires of the following areas (Maliq, Vithkuq, Bulgarec Drithas, Libonik, Lozhan, Mollas, Pirg, Pojan,). The second questionnaire reflects the current situation of 150 specialists, traders, processing businesses of the area of Korca.

We realized panel discussions of experts, to assess barriers, factors and policies in favor of the growth of FDI flows.

Method / comparative analysis to analyze the comparative advantages of the country or sector related to FDI, and to assess rates and differences between countries, regions and sectors in this regard.

We use economic methods to analyze competitive or comparative advantages of the country associated with the products, sectors, prioritized areas for FDI.

\section{Results}

\subsection{Barriers to the sale of agricultural products by zone}

Table 1. a- Shortage of production b-Low quality products c-Lack of market information d-Long distance from the market e-Poor road infrastructure f-Poor collection infrastructure g-Lack of storage hLimited agro-processing infrastructure $\mathrm{i}$-The difficult in transportation j-Unfair competition

\begin{tabular}{|l|c|c|c|c|c|c|c|c|c|c|}
\hline & a) & b) & c) & d) & e) & f) & g) & h) & i) & j) \\
\hline BULGAREC & 2.45 & 2.52 & 1.90 & 2.00 & 2.34 & 2.28 & 2.93 & 2.52 & 3.24 & 4.21 \\
\hline DRITHAS & 3.50 & 4.00 & 1.50 & 2.00 & 1.50 & 2.50 & 2.50 & 1.50 & 1.50 & 4.00 \\
\hline LIBONIK & 2.17 & 1.94 & 2.22 & 1.53 & 1.50 & 2.50 & 2.56 & 1.89 & 2.22 & 3.08 \\
\hline LOZHAN & 1.33 & 1.00 & 2.33 & 2.67 & 2.00 & 2.00 & 2.33 & 3.33 & 2.33 & 3.33 \\
\hline MALIQ & 2.50 & 2.45 & 2.58 & 2.10 & 2.78 & 2.58 & 2.33 & 1.83 & 2.20 & 4.15 \\
\hline MOLLAS & 1.33 & 0.83 & 4.00 & 2.50 & 2.50 & 4.00 & 4.83 & 2.83 & 4.33 & 4.50 \\
\hline GORE & 2.00 & 1.00 & 5.00 & 2.00 & 4.00 & 3.00 & 3.00 & 4.00 & 4.00 & 5.00 \\
\hline PIRG & 1.44 & 1.61 & 2.33 & 2.06 & 1.94 & 2.83 & 2.72 & 2.33 & 3.00 & 3.33 \\
\hline POJAN & 1.00 & 1.71 & 2.57 & 2.00 & 1.57 & 2.00 & 2.43 & 1.71 & 1.57 & 3.29 \\
\hline VITHKUQ & 2.20 & 2.20 & 4.20 & 4.40 & 4.20 & 4.80 & 2.60 & 4.80 & 3.00 & 4.20 \\
\hline Grand Total & $\mathbf{2 . 1 4}$ & $\mathbf{2 . 1 1}$ & $\mathbf{2 . 4 4}$ & $\mathbf{2 . 0 3}$ & $\mathbf{2 . 2 3}$ & $\mathbf{2 . 6 3}$ & $\mathbf{2 . 6 7}$ & $\mathbf{2 . 2 2}$ & $\mathbf{2 . 6 0}$ & $\mathbf{3 . 7 6}$ \\
\hline & & & & & & & & & & \\
\hline
\end{tabular}


Respondents rank the following factors as obstacles to the sale of products, unfair competition, storage, lack of information collection, difficulty of transport, etc. by percentage.

\subsection{How positively affect these factors the business climate (0-3 points)}

Table 2. Respondents have brought to attention that a greater percentage that positively affects the business climate is (n) the high demand for agricultural products and $(p)$ today's standards of food safety, $(f),(h)$.

\begin{tabular}{|l|c|c|c|c|c|c|c|c|c|c|c|c|c|c|c|}
\hline Komuna & $\mathrm{a}$ & $\mathrm{b}$ & $\mathrm{c}$ & $\mathrm{d}$ & $\mathrm{e}$ & $\mathrm{f}$ & $\mathrm{i}$ & $\mathrm{g}$ & $\mathrm{h}$ & $\mathrm{j}$ & $\mathrm{k}$ & $\mathrm{l}$ & $\mathrm{m}$ & $\mathrm{n}$ & $\mathrm{p}$ \\
\hline BULGAREC & 1.93 & 0.38 & 1.66 & 0.59 & 1.79 & 1.72 & 1.90 & 0.45 & 1.72 & 1.66 & 1.66 & 0.90 & 1.86 & 1.93 & 1.97 \\
\hline DRITHAS & 0.00 & 0.00 & 1.00 & 1.00 & 1.00 & 2.00 & 1.00 & 1.00 & 2.00 & 2.00 & 2.00 & 1.00 & 2.00 & 2.00 & 2.00 \\
\hline LIBONIK & 0.86 & 0.92 & 1.14 & 1.14 & 1.17 & 1.58 & 1.06 & 0.67 & 1.58 & 1.36 & 1.61 & 1.14 & 1.47 & 1.58 & 1.47 \\
\hline LOZHAN & 1.00 & 1.00 & 1.33 & 1.67 & 1.00 & 1.00 & 1.67 & 1.67 & 1.00 & 1.33 & 1.33 & 1.33 & 1.33 & 2.00 & 2.00 \\
\hline MALIQ & 0.88 & 0.75 & 1.40 & 1.48 & 1.33 & 1.45 & 0.88 & 0.83 & 1.45 & 1.05 & 1.40 & 0.93 & 1.33 & 1.40 & 1.28 \\
\hline MOLLAS & 0.00 & 0.33 & 0.83 & 0.67 & 0.33 & 1.00 & 0.33 & 0.67 & 1.00 & 0.50 & 0.67 & 0.83 & 0.67 & 1.17 & 0.83 \\
\hline GORE & 0.00 & 0.00 & 0.00 & 1.00 & 1.00 & 0.00 & 1.00 & 0.00 & 0.00 & 0.00 & 2.00 & 2.00 & 0.00 & 1.00 & 0.00 \\
\hline PIRG & 0.83 & 1.06 & 1.44 & 1.39 & 1.11 & 1.17 & 1.17 & 0.89 & 1.17 & 1.22 & 1.50 & 1.50 & 1.89 & 1.67 & 1.67 \\
\hline POJAN & 1.29 & 1.71 & 2.00 & 2.29 & 1.71 & 2.00 & 1.71 & 1.29 & 2.00 & 2.00 & 2.29 & 2.14 & 1.57 & 2.00 & 2.14 \\
\hline VITHKUQ & 0.20 & 0.20 & 0.80 & 0.20 & 0.20 & 0.40 & 0.00 & 0.80 & 0.40 & 0.40 & 0.80 & 0.60 & 0.40 & 1.40 & 1.00 \\
\hline Grand Total & 1.03 & $\mathbf{0 . 7 6}$ & 1.36 & 1.16 & 1.28 & 1.46 & 1.16 & $\mathbf{0 . 7 5}$ & 1.46 & 1.27 & 1.51 & 1.10 & 1.49 & 1.62 & 1.53 \\
\hline
\end{tabular}

\begin{tabular}{|l|}
\hline Factors \\
\hline a- Environment and political stability \\
\hline b- Corrupt practices in business \\
\hline c- The degree of environmental regulation \\
\hline d- The level of taxes \\
\hline e- Government agricultural policies \\
\hline f- Unfair competition in the market \\
\hline g- Current bank interest rates \\
\hline h- Today's road infrastructure \\
\hline i- Farm size and fragmentation \\
\hline j- The actual cost of production resources \\
\hline k- Irrigation and drainage infrastructure \\
\hline - Little desire to work in group \\
\hline m- The security of property rights \\
\hline n- Referral today for agricultural products \\
\hline p- Today's standards of food safety \\
\hline
\end{tabular}

\subsection{Willingness to invest (0-3 points)}

Table 3. The willingness to invest in fruits production, than in milk and vegetables.

\begin{tabular}{|l|c|c|c|c|c|c|c|}
\hline & Fruits & Grapes & Vegetables & Milk & Agro- processing & Storage & Agro-tourism \\
\hline BULGAREC & 0.79 & 0.31 & 1.34 & 1.10 & 0.59 & 0.62 & 0.41 \\
\hline DRITHAS & 1.00 & 0.00 & 0.00 & 3.00 & 0.00 & 1.00 & 1.00 \\
\hline LIBONIK & 1.25 & 0.83 & 1.19 & 1.56 & 0.75 & 0.67 & 0.36 \\
\hline LOZHAN & 2.00 & 0.67 & 1.00 & 0.33 & 0.67 & 0.67 & 0.67 \\
\hline MALIQ & 1.68 & 1.03 & 1.65 & 1.33 & 0.63 & 0.93 & 0.75 \\
\hline MOLLAS & 3.00 & 0.17 & 0.00 & 0.17 & 1.00 & 1.00 & 0.33 \\
\hline GORE & 3.00 & 0.00 & 0.00 & 0.00 & 1.00 & 1.00 & 0.00 \\
\hline PIRG & 2.22 & 0.72 & 0.61 & 1.83 & 0.61 & 0.67 & 0.44 \\
\hline POJAN & 1.86 & 0.86 & 1.29 & 2.00 & 0.86 & 1.00 & 1.00 \\
\hline VITHKUQ & 1.40 & 0.20 & 0.40 & 1.60 & 0.60 & 0.80 & 1.00 \\
\hline Grand Total & 1.53 & 0.71 & 1.18 & 1.38 & 0.67 & 0.77 & 0.55 \\
\hline
\end{tabular}




\section{The Economic Situation of the Area Farms}

\subsection{Analyzes 2}

\section{The Climate and Investment According to Specialists}

\subsection{The factors that affects the climate}

Hypotheses: The business climate in agriculture depends positively on irrigation infrastructure and competition in the markets, the level of taxes and the environment and political stability, and current farm size.

\begin{tabular}{|c|c|c|c|c|}
\hline \multicolumn{5}{|c|}{$\begin{array}{l}\text { Dependent Variable: The climate } \\
\text { Method: ML - Binary Logit } \\
\text { Sample: } 1150 \\
\text { Included observations: } 150 \\
\text { Convergence achieved after } 4 \text { iterations } \\
\text { Covariance matrix computed using second derivatives }\end{array}$} \\
\hline $\begin{array}{l}\text { Variable } \\
\end{array}$ & Coefficient & Std. Error & z-Statistic & Prob. \\
\hline $\begin{array}{c}\mathrm{C} \\
\text { UJ } \\
\text { Competition }\end{array}$ & $\begin{array}{r}-3.428832 \\
1.082884 \\
0.787056 \\
\end{array}$ & $\begin{array}{l}0.556049 \\
0.254276 \\
0.223082 \\
\end{array}$ & $\begin{array}{c}-6.166425 \\
4.258686 \\
3.528096 \\
\end{array}$ & $\begin{array}{l}0.0000 \\
0.0000 \\
0.0004 \\
\end{array}$ \\
\hline $\begin{array}{l}\text { Mean dependent variable } \\
\text { S.E. of regression } \\
\text { Sum squared reside } \\
\text { Log likelihood } \\
\text { Restr. log likelihood } \\
\text { LR statistic (2 df) } \\
\text { Probability(LR stat) } \\
\end{array}$ & $\begin{array}{l}0.460000 \\
0.395419 \\
22.98440 \\
-72.07860 \\
-103.4916 \\
62.82592 \\
2.28 \mathrm{E}-14 \\
\end{array}$ & \multicolumn{2}{|c|}{$\begin{array}{l}\text { S.D. dependent variable } \\
\text { Akaike info criterion } \\
\text { Schwarz criterion } \\
\text { Hannan-Quinn criteria } \\
\text { Avg. log likelihood } \\
\text { McFadden R-squared }\end{array}$} & $\begin{array}{c}0.500067 \\
1.001048 \\
1.061261 \\
1.025511 \\
-0.480524 \\
0.303532\end{array}$ \\
\hline $\begin{array}{l}\text { Obs with } \mathrm{Dep}=0 \\
\text { Obs with } \mathrm{Dep}=1\end{array}$ & \multicolumn{2}{|c|}{$\begin{array}{l}81 \text { Total obs } \\
69\end{array}$} & & 150 \\
\hline
\end{tabular}

It has been proved that the perception of the business climate is positively related to the perception of the role of irrigation and competition in markets. In other words, if irrigation and improved competitiveness in the markets, it will improve the business climate. By comparison, irrigation is the most important factor.

Dependent Variable: KLIMA

Method: ML - Binary Logit

Sample: 1150

Included observations: 150

Convergence achieved after 3 iterations

Covariance matrix computed using second derivatives

\begin{tabular}{|c|c|c|c|c|}
\hline Variable & Coefficient & Std. Error & z-Statistic & Prob. \\
\hline C & -2.925726 & 0.609631 & -4.799174 & 0.0000 \\
\hline TAT & 1.271364 & 0.280494 & 4.532587 & 0.0000 \\
\hline MJ POL & 0.799910 & 0.392370 & 2.038660 & 0.0415 \\
\hline Mean dependent var & 0.460000 & \multicolumn{2}{|c|}{ S.D. dependent var } & 0.500067 \\
\hline S.E. of regression & 0.444663 & \multicolumn{2}{|c|}{ Akaike info criterion } & 1.200579 \\
\hline Sum squared resid & 29.06565 & \multicolumn{2}{|c|}{ Schwarz criterion } & 1.260792 \\
\hline Log likelihood & -87.04345 & \multicolumn{2}{|c|}{ Hannan-Ouinn criter. } & 1.225042 \\
\hline Restr. log likelihood & -103.4916 & \multicolumn{2}{|c|}{ Avg. log likelihood } & -0.580290 \\
\hline LR statistic (2 df) & 32.89623 & \multicolumn{2}{|c|}{ McFadden R-squared } & 0.158932 \\
\hline Probability(LR stat) & 7.19E-08 & & & \\
\hline Obs with Dep $=0$ & \multirow{2}{*}{\multicolumn{2}{|c|}{81 Total obs }} & & 150 \\
\hline Obs with Dep=1 & & 69 & & \\
\hline
\end{tabular}

The Climate $=\overline{\overline{1-@ L O G I T\left(-\left(-2.925726305+1.271363553^{*} \mathrm{TAT}\right.\right.}}=\overline{\overline{0.7999101767^{*}}} \overline{\overline{\mathrm{POL}))}}$ 
It proved that the perception of the business climate is positively related to the perception of the role of the political environment and the level of taxes. In other words, if these factors improve, it will improve business climate. By comparison, the level of taxes is the most important factor of political environment.

\begin{tabular}{|c|c|c|c|c|}
\hline \multicolumn{5}{|c|}{$\begin{array}{l}\text { Dependent Variable: The climate } \\
\text { Method: ML - Binary Logit } \\
\text { Sample: } 1150 \\
\text { Included observations: } 150 \\
\text { Convergence achieved after } 3 \text { iterations } \\
\text { Covariance matrix computed using second derivatives }\end{array}$} \\
\hline Variable & Coefficient & Std. Error & z-Statistic & Prob. \\
\hline $\begin{array}{c}\text { C } \\
\text { FERM }\end{array}$ & $\begin{array}{c}-0.731259 \\
0.582855 \\
\end{array}$ & $\begin{array}{l}0.290543 \\
0.242308\end{array}$ & $\begin{array}{c}-2.516872 \\
2.405431 \\
\end{array}$ & $\begin{array}{l}0.0118 \\
0.0162\end{array}$ \\
\hline $\begin{array}{l}\text { Mean dependent var } \\
\text { S.E. of regression } \\
\text { Sum squared resid } \\
\text { Log likelihood } \\
\text { Restr. log likelihood } \\
\text { LR statistic (1 df) } \\
\text { Probability(LR stat) } \\
\end{array}$ & $\begin{array}{r}0.460000 \\
0.491183 \\
35.70657 \\
-100.3998 \\
-103.4916 \\
6.183477 \\
0.012895 \\
\end{array}$ & \multicolumn{2}{|c|}{$\begin{array}{l}\text { S.D. dependent var } \\
\text { Akaike info criterion } \\
\text { Schwarz criterion } \\
\text { Hannan-Quinn criter. } \\
\text { Avg. log likelihood } \\
\text { McFadden R-squared }\end{array}$} & $\begin{array}{r}0.500067 \\
1.365331 \\
1.405473 \\
1.381639 \\
-0.669332 \\
0.029874\end{array}$ \\
\hline $\begin{array}{l}\text { Obs with } \mathrm{Dep}=0 \\
\text { Obs with } \mathrm{Dep}=1\end{array}$ & \multicolumn{2}{|c|}{$\begin{array}{l}81 \text { Total obs } \\
69\end{array}$} & & 150 \\
\hline
\end{tabular}

It has been proved that the general assessment for the business climate is positively related to agriculture from current farm size.

\section{The Climate Depending on what Needs to be Improved to Encourage Foreign Investment}

Hypotheses: The improvement of cooperation, stability and political environment and the reduction of tax levels and the informal economy as a factor deemed important for the business climate and encouraging foreign investment in agriculture.

Dependent Variable: The climate

Method: ML - Binary Logit

Sample: 1150

Included observations: 150

Convergence achieved after 3 iterations

Covariance matrix computed using second derivatives

\begin{tabular}{lcllc}
\hline \hline \multicolumn{1}{c}{ Variable } & Coefficient & Std. Error & z-Statistic & Prob. \\
\hline \multicolumn{1}{c}{ C } & 1.683812 & 0.535432 & 3.144772 & 0.0017 \\
KOOP & -0.633966 & 0.176338 & -3.595178 & 0.0003 \\
\hline \hline Mean dependent var & 0.460000 & S.D. dependent var & 0.500067 \\
S.E. of regression & 0.477500 & Akaike info criterion & 1.309761 \\
Sum squared resid & 33.74496 & Schwarz criterion & 1.349903 \\
Log likelihood & -96.23208 & Hannan-Quinn criter. & 1.326069 \\
Restr. log likelihood & -103.4916 & Avg. log likelihood & -0.641547 \\
LR statistic (1 df) & 14.51897 & McFadden R-squared & 0.070146 \\
Probability(LR stat) & 0.000139 & & \\
\hline \hline
\end{tabular}

\begin{tabular}{lll}
\hline \hline Obs with Dep $=0$ & 81 Total obs & 150 \\
Obs with Dep=1 & 69
\end{tabular}

The climate $=\overline{\overline{1-@ L O G I T\left(-\left(1.68381239-0.6339656993^{*} \mathrm{KO}\right.\right.}} \overline{\overline{\mathrm{OP}}))}$ 
If the business climate is perceived low, the need for improvement in cooperation is great.

Dependent Variable: The climate

Method: ML - Binary Logit

Sample: 1150

Included observations: 150

Convergence achieved after 4 iterations

Covariance matrix computed using second derivatives

\begin{tabular}{|c|c|c|c|c|}
\hline Variable & Coefficient & Std. Error & z-Statistic & Prob. \\
\hline C & 5.493796 & 1.315953 & 4.174765 & 0.0000 \\
\hline MJPOL & -0.499546 & 0.229452 & -2.177123 & 0.0295 \\
\hline TAKS & -0.591961 & 0.233861 & -2.531249 & 0.0114 \\
\hline INFORMAL & -0.509562 & 0.243042 & -2.096595 & 0.0360 \\
\hline Mean dependent var & 0.460000 & \multicolumn{2}{|c|}{ S.D. dependent var } & 0.500067 \\
\hline S.E. of regression & 0.466061 & \multicolumn{2}{|c|}{ Akaike info criterion } & 1.268849 \\
\hline Sum squared resid & 31.71302 & \multicolumn{2}{|c|}{ Schwarz criterion } & 1.349133 \\
\hline Log likelihood & -91.16368 & \multicolumn{2}{|c|}{ Hannan-Quinn criter. } & 1.301466 \\
\hline Restr. Iog likelihood & -103.4916 & \multicolumn{2}{|c|}{ Avg. log likelihood } & -0.607758 \\
\hline LR statistic (3 df) & 24.65577 & \multicolumn{2}{|c|}{ McFadden R-squared } & 0.119120 \\
\hline Probability(LR stat) & $1.82 \mathrm{E}-05$ & & & \\
\hline Obs with $\mathrm{Dep}=0$ & \multicolumn{3}{|c|}{81 Total obs } & 150 \\
\hline Obs with $\mathrm{Dep}=1$ & \multicolumn{2}{|c|}{69} & & \\
\hline
\end{tabular}

The improvement of the political environment, the reduction of informality and taxes of those who want more of quoting lower business climate; or if the business climate is perceived low, the need for improvement in these areas is huge. Negative coefficients indicate how close lower is the business climate, the greater is the need for improvements in these areas. The need to reduce taxes somewhat greater feels the need to improve the informality and political environment, whether to improve the business climate.

\section{Conclusions and Recomandations}

According to the data processing, we could conclude that the inflow of FDI has contributed positively to employment and economic growth in Albania, but Albania has more space for FDI.

- The inflow of FDI in Albania has contributed to increasing productivity, facilitating access to markets and improve the trade balance.

- Small property and other structural problems in agriculture are serious obstacles to FDI. These obstacles are expected to be long, hindering the growth of FDI in the long term.

- The study conducted showed that the business climate, in particular, fair competition, fiscal facilities and facilities at the entrance of capital and repatriation of profits, security of investments and property, are important factors for increasing the flow of FDI also in Albania. The business climate in Albania has been improved.

- Agriculture has the competitive advantage in relation to other branches of FDI, but policies are needed to reduce structural barriers, increasing security of property and fiscal facilities (since these factors mare in the study emerged that impact and are important).

\section{Questionnaires Results}

According to the data processing, we could conclude that:

- The business climate in agriculture depends on irrigation positively infrastructure and competition in the markets, the level of taxes and the environment and political stability, as well as the actual size of the farm.

- The improvement of cooperation, stability and political environment, the reduction of taxes and the informal economy is an important factor thought the business climate and encouraging foreign investment in the agriculture sector.

- Improving the political environment, the elimination of informality and reducing taxes and require more who 
sits quoting business climate; or if the business climate is perceived low, the need for improvement in these areas is huge. (J) Negative coefficients indicate how close lower business climate, the greater is the need for improvements in these areas.

- The need to reduce taxes feels somewhat greater need for improving the informality and political environment to be improved if the business climate.

Based on the responses to the survey, the results show that:

Most of the respondents (69 of them) believe the situation in business fixed after a year, but a significant number of 77 of them thinks that the larger improvement. The obstacles of agricultural products sale are considered unfair competition, poor agro-processing development and storage.

Most experts consider the business climate less favorable to agriculture, or rather between little and very favorable.

The political environment and the size of the farm are more negative factors about the willingness to invest. In general, all factors play a stronger role in promoting the readiness to invest.

The banks' loans improvement, the reduction of business informality and improvement of the policy environment, the reduction of taxes, improvement of irrigation and drainage, considered as the most important factors to promote foreign investment in the agricultural sector. Willingness to invest in the production of fruit depends on gender and type of farm, the farmer's age, distance from the market and the perception of the current state of the business climate, and the amount of land owned.

The current situation in agriculture in the region of Korca is satisfactory but there is room for improvement.

\section{References}

http://data.worldbank.org/country/albania (Economy Growth).

http://www.instat.gov.al/en/Home.aspx

www.bankofalbania.org

http://www.aida.gov.al/

http://www.deloitte.com/al/en.html

http://www.bujqesia.gov.al/

http://en.wikipedia.org/wiki/Solow\%E2\%80\%93Swan_model

Te dhena -Bashkia Maliq

"Motivimet e investitorëve të huaj për të investuar në Shqipëri"- studim i kryer nga OECD (Organizata per Koperimin Ekonomik dhe Zhvillimin)

Draft strategjia FINAL Janar 2014,AIDA

Bank of Albania (2009)/Business and Investment development Strategy/http://www.dsdc.gov.al/.../business_and_investment_ development_strategy_151_1.pdf (page 45) accessed 25.01.2010

Zhvillimin Bujqësor në Evropën Qendrore dhe Lindore, vëllimi 57, pp. 37-62.

Ministria e Bujqësisë, Ushqimit dhe Mbrojtjes së Konsumatorit (MBUMK) (2007). Strategjia për sektorin e bujqësisë dhe ushqimit 20072013. Tiranë (MADA) (2011) .OECD (2010). South East Europe - Investment

Republika e Shqipërisë (2011). Programi Ekonomik dhe Fiskal 2011-2013.

UNCTAD (WIR11). World Investment Report 2011: Non-equity Modes of International

Open Data (2011), Investimete Huaja Direkte në Shqipëri krahasuar me rajonin,07.07.2011

FMN (2010a). World Economic Outlook:

Agjencia për Zhvillimin e Zonave Malore (MADA) (2011).

Komisioni Evropian (2011). Strategjia e Zgjerimit dhe Sfidat Kryesore 2011-2012,

Konkluzionet për Shqipërinë, Com (2011) 666 final (Bruksel:Komisioni Evropian).

Komisioni Evropian (2010). Strategjia e Zgjerimit dhe Raportet e Progresit 2010.

Conceptualizing the Linkages. Romë: FAO.UNCTAD (WIR09). World Investment 
